\title{
MENINGKATKAN KEMAMPUAN MEMBACA PERMULAAN MENGGUNAKAN MEDIA KARTU KATA BERGAMBAR PADA SISWA KELAS I SEKOLAH DASAR
}

\author{
Eka Teni \\ SDN 7 Pendawan Sambas \\ Email:ekateni12345@yahoo.com
}

\begin{abstract}
Abstrak
Penulisan artikel ini dilatarbelakangi oleh beberapa hal diantaranya Berdasarkan tes kemampuan membaca dan hasil analisis yang dilakukan oleh guru, menunjukkan hasil yang kurang memuaskan yaitu dari 18 siswa hanya 4 ( $22 \%$ ) siswa yang bisa membaca dengan lancar, 8 atau ( $44 \%$ ) siswa yang membaca dengan cara mengeja kemudian merangkaikannya menjadi kata, dan ada 6 atau ( $34 \%$ ) siswa yang masing mengalami kesulitan untuk membedakan huruf $d$ dan $b$, huruf 1 dan $r$, huruf $p$ dan $t$, mereka sudah bisa mengeja huruf menjadi suku kata tetapi belum mampu merangkaikannya menjadi kata yang dimaksudkan. Tujuan penulisan ini untuk mendeskripsikan kemampuan guru menyususn RPP dan melaksanakan kegiatan pembelajaran serta mendeskripsikan peningkatan kemampuan membaca siswa kelas I SDN 7 Pendawan setelah menggunakan media kartu kata bergambar. Dalam rangka meningkatkan kemampuan membaca dilakukan PTK dengan menggunakan media kartu kata bergambar.Penelitian ini dilaksanakan di SDN 7 Pendawan pada siswa kelas I sebanyak dua siklus. Tehnik pengumpulan data dilakukan dengan menggunakan hasil test kemampuan membaca dan lembar pengamatan. Hasil tes kemampuan membaca siswa dan tingkat ketuntasan juga mengalami peningkatan. Analisis hasil tes kemampuan membaca pada siklus I adalah 72,57 dan siklus II 87,15 , sedangkan ketuntasan rata-rata kemampuan membaca siswa siklus I adalah $66,67 \%$ dan siklus II $87,15 \%$. Berdasarkan paparan di atas dapat disimpulkan bahwa penggunaan media kartu katabergambar dapat meningkatkan kemampuan membaca permulaan pada siswa kelas I SDN7 Pendawan.
\end{abstract}

\section{Kata Kunci: Membaca Permulaan, Media Kartu Kata Bergambar}

\section{PENDAHULUAN}

Membaca memegang peranan yang sangat penting dalam proses pembelajaran, karena pada setiap muatan pembelajaran tidak terlepas dari kemampuan membaca. Kemampuan membaca merupakan dasar untuk menguasai berbagai bidang studi. Oleh karena itu anak harus belajar membaca agar ia dapat membaca untuk belajar (Lerner, 1988). Tahap membaca permulaan umumnya dimulai sejak anak masuk kelas satu SD ( sekolah dasar ), yaitu pada saat berusia sekitar 6-7 tahun. Tujuan utama dari membaca permulaan adalah agar anak dapat mengenal tulisan sebagai lambang atau simbol bahasa sehingga anak-anak dapat menyuarakan tulisan tersebut (Wardani,1995).

Pembelajaran di SD dilaksanakan sesuai dengan perbedaan atas kelas rendah dan kelas tinggi. Pelajaran di kelas rendah biasanya disebut pelajaran membaca permulaan, sedangkan dikelas tinggi disebut pelajaran membaca lanjut. Membaca permulaan merupakan tahap proses belajar membaca bagi siswa sekolah dasar kelas awal (kelas I dan II ) untuk memahami dan menyuarakan tulisan dengan intonasi yang wajar. Siswa belajar untuk memperoleh kemampuan membaca dan menguasai tehnik-tehnik membaca dan menangkap isi bacaan dengan baik, sehingga melalui kemampuan membaca 
yang baik itu akan memungkinkan orang tersebut mampu mempertinggi daya pikirannya, mempertajam pandangannnya dan memperluas wawasannya.

Hasil belajar yang diharapkan dalam pembelajaran membaca permulaan di kelas I SD antara lain siswa dapat membaca nyaring suku kata dengan lafal yang tepat, membaca nyaring kalimat sederhana dengan lafal dan intonasi yang tepat., membaca lancar beberapa kalimat sederhana yang terdiri dari 3-5 kata dengan intonasi yang tepat, serta membaca puisi anak yang terdiri atas 2-4 baris dengan lafal dan intonasi yang tepat (Depdiknas:2007). Kenyataan dilapangan khususnya di kelas I SDN 7 Pendawan, siswa memiliki tingkat kemampuan membaca yang berbeda-beda, beberapa siswa masih sulit untuk membedakan huruf yang hampir sama,seperti huruf $b$ dan $d$, huruf $p$ dan $t$, serta huruf $\mathrm{r}$ dan 1, ada beberapa siswa yang sudah lancar membaca,di karenakan mereka telah mengenal huruf dan mampu merangkaikan huruf menjadi suku kata dan kata, , ada yang masih mengeja dan bahkan ada siswa yang mampu mengeja huruf demi huruf tetapi tidak bisa merangkai/membaca kata yang dimaksudkan. Berdasarkan tes kemampuan membaca dan hasil analisis yang dilakukan oleh guru, menunjukkan hasil yang kurang memuaskan yaitu dari 18 siswa hanya 4 ( $22 \%$ ) siswa yang bisa membaca dengan lancar, 8 atau ( $44 \%$ ) siswa yang membaca dengan cara mengeja kemudian merangkaikannya menjadi kata, dan ada 6 atau ( 34\% ) siswa yang masih mengalami kesulitan untuk membedakan huruf d dan $b$, huruf 1 dan $r$, huruf $\mathrm{p}$ dan $\mathrm{t}$, mereka sudah bisa mengeja huruf menjadi suku kata tetapi belum mampu merangkaikannya menjadi kata yang dimaksudkan.

Berdasarkan hasil analisis seperti yang disebutkan di atas, penulis menyadari mungkin selama ini pembelajaran yang dilaksanakan masih bersifat konvensional, dimana selama berlangsungnya proses belajar mengajar, guru lebih dominan dan kurang memanfaatkan media yang melibatkan siswa untuk memperoleh pengalaman belajar, sehingga pembelajaran yang dilaksanakan menjadi kurang bermakna bagi siswa. Oleh karena itu penulis merasa perlu untuk melakukan perbaikan pembelajaran. Adapun perbaikan pembelajaran yang dilaksanakan untuk meningkatkan kemampuan membaca siswa melalui penggunaan media kartu kata bergambar. Dengan menggunakan media kartu kata bergambar diharapkan siswa terlibat lebih aktif untuk memperoleh pengalaman belajar sehingga siswa merasakan bahwa belajar membaca itu menyenangkan, suasana belajar menjadi lebih aktif dan kondusif, sehingga pada akhirnya dapat meningkatkan kemampuan membaca siswa dan pembelajaran yang dilaksanakan menjadi lebih bermakna.

Menurut Harjasujana

(1996:4) mengemukakan bahwa membaca merupakan proses. Membaca bukanlah proses yang tunggal melainkan sintesa dari berbagai proses yang kemudian berakumulasi pada suatu perbuatan tunggal. Membaca diartikan sebagai pengucapan kata-kata, mengidentifikasi kata dan mencari arti dari sebuah teks. Membaca diawali dari struktur luar bahasa yang terlihat oleh kemampuan visual untuk mendapatkan makna yang terdapatdalam struktur dalam bahasa. Menurut Somadya (2011:1) Membaca merupakan kegiatan interaktif untuk memetik dan memahami makna yang terkandung dalam bahan tertulis lebih lanjut, dikatakan bahwa membaca merupakan proses yang dilakukan dan digunakan oleh pembaca untuk memperoleh pesan yaang disampaikan oleh penulis.

Berdasarkan beberapa pendapat di atas dapat disimpulkan membaca adalah suatu aktifitas yang komplek baik fisik dan psikologis. Proses yang berupa fisik berupakegiatan mengamati tulisan secara visual dan merupakan proses mekanis dalam membaca. Proses mekanis tersebut berlanjut dengan proses psikologis yang berupa kegiatan berpikir dalam mengolah informasi. Proses psikologis itu dimulai ketika indera visual mengirimkan hasil pengamatan terhadap tukisan ke pusat kesadaran melalui sistem syaraf. Melalui proses decoding gambar-gambar bunyi dan kombinasinya itu 
kemudian diidentifikasi, diuraikan, dan diberi makna.

Membaca merupakan proses pengolahan bacaan secara kritis kreatif dengan tujuan memperoleh pemahaman secara menyeluruh tentang suatu bacaan, serta penilaian terhadap keadaan, nilai, dan dampak bacaan. Kegiatan membaca merupakan aktivitas mental memahami apa yang disampaikan penulis melalui teks atau bacaan.

Membaca Permulaan merupakan tahapan proses belajar membaca bagi siswa sekolah dasar kelas awal. Siswa belajar untuk memperoleh kemampuan dan menguasai teknik-teknik membaca dan menangkap isi bacaan dengan baik. Oleh karena itu guru perlu merancang pembelajaran membaca dengan baik sehingga mampu menumbuhkan kebiasan membaca sebagai suatu yang menyenangkan.

Pada tingkatan membaca permulaan, pembaca belum memiliki keterampilan kemampuan membaca yang sesungguhnya, tetapi masih dalam tahap belajar untuk memperoleh keterampilan atau kemampuan membaca. Membaca pada tingkatan ini merupakan kegiatan belajar mengenal bahasa tulis. Melalui tulisan itulah siswa dituntut dapat menyuarakan lambang-lambang bunyi bahasa tersebut, untuk memperoleh kemampuan membaca diperlukan tiga syarat, yaitu kemampuan membunyikan: (1) lambang-lambang tulis, (2) penguasaan kosakata untuk memberi arti, dan (3) emasukkan makna dalam kemahiran bahasa.

Menutur Djago Tarigan (2005:54) langkah awal yang paling penting di dalam pembelajaran membaca permulaan adalah bagaimana menarik minat dan perhatian siswa agar mereka merasa tertarik dengan buku (bacaan) dan mau belajar dengan keinginannya sendiri, tanpa merasa terpaksa untuk melakukannya. Sedangkan St. Y. Slamet (2009:98) mengatakan bahwa membaca memerlukan keterampilan karena diperlukan latihan-latihan yang berkelanjutan, terus menerus dan sungguh-sungguh.

Pelaksanaan membaca permulaan di kelas I sekolah dasar dilakukan dalam dua tahap, yaitu membaca periode tanpa buku dan membaca dengan menggunakan buku. Pembelajaran membaca tanpa buku dilakukan dengan cara mengajar dengan menggunakan media atau alat peraga selain buku misalnya kartu gambar, kartu huruf, kartu kata dan kartu kalimat. Pembelajaran membaca dengan buku merupakan kegiatan membaca dengan menggunakan buku sebagai bahan pelajaran.

Belajar merupakan kegiatan fisik dan mental, sehingga perubahan yang ada harus tergambar pada perkembangan fisik dan mental siswa, keberhasilan belajar siswa dapat diukur berdasarkan pada besarnya rentang perubahan sebelum dan sesudah siswa mengikuti kegiatan belajar. Dari proses belajar mengajar itu diharapkan terjadinya perubahan-perubahan dan itulah yang dinamakan hasil belajar. Menurut Suharsimi Arikunto " hasil belajar adalah hasil akhir setelah mengalami proses belajar, dimana perubahan itu tampak dalam bentuk yang dapat diamati dan diukur ".

Menurut Oemar Hamalik hasil belajar adalah bila seseorang telah belajar akan terjadi perubahan tingkah laku pada orang tersebut, misalnya dari tidak tahu menjadi tahu, dan dari tidak mengerti menjadi mengerti. Selanjutnya sesuai teori Taksonomi Bloom hasil belajar dalam rangka studi dicapai rnelalui tiga kategori ranah antara lain kognitif, afektif, psikomotor. Perinciannya adalah sebagai berikut.

1. Ranah Kognitif

Berkenaan dengan hasil belajar intelektual yang terdiri dari 6 aspek yaitu pengetahuan, pemahaman, penerapan, analisis, sintesis dan penilaian.

2. Ranah Afektif

Berkenaan dengan sikap dan nilai. Ranah afektif meliputi lima jenjang kemampuan yaitu menerima, menjawab atau reaksi, menilai, organisasi dan karakterisasi dengan suatu nilai atau kompleks nilai.

3. Ranah Psikomotor

Meliputi keterampilan motorik, manipulasi benda-benda, koordinasi neuromuscular (menghubungkan, mengamati).

Dari uraian di atas yang dimaksud dengan hasil belajar dalam penelitian ini adalah perubahan kemampuan membaca 
permulaan yang dimiliki siswa kelas I yang dinyatakan dengan nilai yang diperoleh siswa berdasarkan hasil test kemampuan membaca permulaan yang diberikan sesudah pembelajaran dengan memanfaatkan media kartu kata.

\section{Media Kartu Kata Bergambar}

Media pembelajaran mempunyai peranan yang penting dalam proses kegiatan belajar mengajar. Dengan adanya media, proses kegiatan belajar mengajar akan semakin dirasakan manfaatnya. Penggunaan media diharapkan akan menimbulkan dampak positif, seperti timbulnya proses pembelajaran yang lebih kondusif, terjadi umpan balik dalam proses belajar mengajar, dan mencapai hasil yang optimal.

Media pembelajaran merupakan suatu bentuk peralatan, metode, atau teknik yang digunakan menyalurkan pesan, membantu mempertegas bahan pelajaran, sehingga dapat merangsang pikiran, perasaan, perhatian dan minat siswa dalam proses belajar. Dalam hal ini penerima pesan adalah siswa. Jadi sebaiknya dalam pembelajaran membaca permulaan tidak lepas dari penggunaan media.

Menurut Kamus Besar Bahasa Indonesia kartu adalah kertas tebal berbentuk persegi panjang, Kata adalah unsur bahasa yang diucapkan atau dituliskan yang merupakan perwujudan kesatuan perasaan dan pikiran yang dapat digunakan dalam berbahasa. Sedangkan gambar adalah tiruan barang (orang, binatang, tumbuhan, dan sebagainya) yang dibuat dengan coretan pensil, alat tulis, dll pada kertas atau sejenisnya. Jadi kartu kata bergambar adalah kertas tebal yang tertulis unsur bahasa yang mempunyai gambar sesuai dengan unsur bahasa tersebut. Sejalan dengan Mohammad Jaruki (2008: 15) bahwa kartu kata bergambar adalah kartu yang berisi kata-kata dan terdapat gambar. Dalam penelitian ini, kartu kata bergambar yang dimaksud adalah kartu tebal yang bergambar benda-benda di sekitar anak seperti binatang, tumbuhan, buah, maupun peralatan sekolah yang mempunyai variasi warna dan tertulis kata pada setiap kartunya.
Keuntungan media kartu kata bergambar adalah mempermudah bagi peserta didik untuk memahami pembelajaran yang berlangsung, karena dengan kartu kata tersebut materi akan mudah diulangi sehingga pemahaman anak akan optimal. Desain gambar yang menarik akan membuat anak lebih tertarik untuk mengikuti pembelajaran. Kelebihan media kartu kata bergambar sebagai media gambar menurut Arif S. Sadiman dkk (1986: 29) mengemukakan sebagai berikut:

a. Sifatnya konkrit gambar atau foto lebih realistis menunjukkan pokok masalah dibandingkan dengan media verbal semata.

b. Gambar dapat mengatasi batasan ruang dan waktu.

c. Tidak semua benda, objek atau peristiwa dapat dibawa ke kelas dan tidak selalu bisa dibawa (diperlihatkan) ke obyek peristiwa tersebut.

d. Media gambar atau foto dapat mengatasi keterbatasan pengamatan.

e. Dapat memperjelas suatu masalah dibidang apa saja dan untuk tingkat usia berapa saja, sehingga dapat mencegah atau membentuk pemahaman.

f. Murah harganya, mudah untuk didapat dan digunakan tanpa memerlukan peralatan khusus.

\section{Pembahasan \\ Kemampuan Guru Menyusun Rencana Pembelajaran}

Berdasarkan hasil observasi yang telah dilakukan dalam dua siklus kegiatan pelaksanaan tindakan kelas diperoleh data bahwa kemampuan guru menyusun RPP mengalami peningkatan. Untuk itu di bawah ini ditampilkan data-data yang menunjukkan peningkatan-peningkatan sebagai berikut: 
Tabel 1. Rekapitulasi Kemampuan Guru Menyusun RPP

\begin{tabular}{clcc}
\hline No & \multicolumn{1}{c}{ Aspek yang Diamati } & $\begin{array}{c}\text { Rata-rata skor } \\
\text { Siklus I }\end{array}$ & $\begin{array}{c}\text { Rata-rata skor } \\
\text { siklus II }\end{array}$ \\
\hline 1. & Tujuan Pembelajaran & 4,00 & 4,00 \\
\hline 2. & Pemilihan Materi Ajar & 4,00 & 4,00 \\
\hline 3. & Pengorganisasian materi ajar & 3.67 & 4,00 \\
\hline 4. & Pemilihan media ajar & 3,00 & 4,00 \\
\hline 5. & Kejelasan skenario pembelajaran & 3,67 & 4,00 \\
\hline 6. & Kerincian skenario pembelajaran & 3,67 & 4,00 \\
\hline 7. & Evaluasi & 4,00 & 4,00 \\
\hline 8 & Kelengkapan instrumen evaluasi & 3,75 & 4,00 \\
\hline \multicolumn{2}{c}{ Jumlah Skor } & 29,76 & 32,00 \\
\hline \multicolumn{2}{c}{ Rata-rata skor } & 3,72 & 4,00 \\
\hline
\end{tabular}

Dari tabel di atas dapat dilihat bahwa rata-rata skor kemampuan guru menyusun RPP pada siklus I adalah 3,72 dan pada siklus II mengalami peningkatan menjadi 4,00, peningkatan sebesar $(0,28 \%)$.

\section{Kemampuan Guru Melaksanakan Pembelajaran \\ Berdasarkan hasil observasi} kemampuan guru melaksanakan pembelajaran dengan menggunakan media kartu kata, pada siklus I selama berlangsungnya proses pembelajaran guru dan siswa belum terbiasa menggunakan media kartu kata dan kartu gambar, sehingga masih mengalamai kendalakendala seperti ketika berdiskusi memasangkan kartu gambar dan kartu kata,

Tabel 2. Rekapitulasi Kemampuan Guru Melaksanakan Pembelajaran

\begin{tabular}{cccc}
\hline & & $\begin{array}{c}\text { Rata- } \\
\text { Rata }\end{array}$ & $\begin{array}{c}\text { Rata- } \\
\text { Rata } \\
\text { No }\end{array}$ \\
& Aspek yang Diamati & Skor & Skor \\
& & Siklus \\
I & Siklus \\
& & II \\
\hline $1 . \quad$ Kegiatan Awal & 4,00 & 4,00
\end{tabular}

2. Kegiatan Inti : beberapa siswa kurang fokus dan lebih banyak bermain menggunakan kartu gambar, selain itu ukuran huruf yang digunakan pada kartu kata agak kecil, sehingga kurang jelas jika dilihat oleh siswa yang duduk dibelakang. Namun pada siklus II guru berupaya memperbaiki kegiatan pembelajaran seperti lebih intensif membimbing siswa ketika berdiskusi, membaca dengan menggunakan media kartu kata dan kartu gambar yang telah dipasangkan ,sehingga suasana pembelajaran lebih menyenangkan dan siswa tampak termotivasi untuk belajar membaca. Meningkatnya kemampuan guru dalam melaksanakan pembelajaran dapat dilihat pada tabel berikut ini:

\begin{tabular}{|c|c|c|c|}
\hline & $\begin{array}{l}\text { a. Mengamati } \\
\text { b. Menanya }\end{array}$ & $\begin{array}{l}4,00 \\
4,00\end{array}$ & $\begin{array}{l}4,00 \\
4,00\end{array}$ \\
\hline & c. Mencoba & 3,25 & 4,00 \\
\hline & d. Menalar & 3.67 & 4,00 \\
\hline & e. Mengasosiasi & 3.67 & 4,00 \\
\hline 3. & Kegiatan Penutup & 3.83 & 4,00 \\
\hline & Jumlah Skor & 26,42 & 28,00 \\
\hline & Rata-rata skor & 3,77 & 4,00 \\
\hline
\end{tabular}


Berdasarkan tabel di atas dapat dilihat bahwa rata-rata skor kemampuan guru kelaksanakan pembelajaran pada siklus I adalah 3,77 dan pada siklus II mengalami peningkatan menjadi 4,00 ( peningkatan sebesar 0,23).

Menganalisis Rata - Rata Kemampuan Membaca Siswa setelah Menggunakan Media Kartu Kata Bergambar.

Kemampuan membaca pada siswa

kelas I SDN 7 Pendawan sebelum menggunakan media kartu kata masih tergolong rendah ( hanya 4 siswa dari 18 siswa) yang bisa membaca dengan lancar, Setelah diberikan pembelajaran membaca dengan menggunakan media kartu kata dan kartu gambar ( siklus I dan siklus II ) tampak adanya peningkatan kemampuan membaca siswa yang diperoleh dari hasil tes kemampuan membaca. Peningkatan kemampuan membaca siswa dapat dilihat pada tabel di berikut ini:

Tabel 3. Rekapitulasi Hasil Tes Kemampuan Membaca Siswa

\begin{tabular}{|c|c|c|c|c|c|c|c|}
\hline \multirow[b]{2}{*}{ No } & \multirow[b]{2}{*}{ Nama Siswa } & \multicolumn{6}{|c|}{ Nilai Siklus I dan Siklus II } \\
\hline & & Siklus I & KKM & Ket & $\begin{array}{l}\text { Siklus } \\
\text { II }\end{array}$ & $\begin{array}{l}\text { KK } \\
M\end{array}$ & Ket \\
\hline 1. & ANP & 81,25 & \multirow{18}{*}{65} & $\mathrm{~T}$ & 100,00 & \multirow{18}{*}{65} & $\mathrm{~T}$ \\
\hline & $\mathrm{BL}$ & 50,00 & & TT & 62,50 & & TT \\
\hline 3. & DW & 62.50 & & TT & 75,00 & & $\mathrm{~T}$ \\
\hline 4. & IP & 100,00 & & $\mathrm{~T}$ & 100,00 & & $\mathrm{~T}$ \\
\hline 5. & JT & 62,50 & & TT & 81,25 & & $\mathrm{~T}$ \\
\hline 6. & KM & 100,00 & & $\mathrm{~T}$ & 100,00 & & $\mathrm{~T}$ \\
\hline 7. & KH & 50,00 & & TT & 62,50 & & TT \\
\hline 8. & MAA & 68,75 & & $\mathrm{~T}$ & 87,50 & & $\mathrm{~T}$ \\
\hline 9. & NT & 56,25 & & TT & 81,25 & & $\mathrm{~T}$ \\
\hline 10. & RAP & 100,00 & & $\mathrm{~T}$ & 100,00 & & $\mathrm{~T}$ \\
\hline 11. & RA & 75,00 & & $\mathrm{~T}$ & 93,75 & & $\mathrm{~T}$ \\
\hline 12. & $\mathrm{RS}$ & 62,50 & & TT & 87,50 & & $\mathrm{~T}$ \\
\hline 13. & SR & 100,00 & & $\mathrm{~T}$ & 100,00 & & $\mathrm{~T}$ \\
\hline 14. & SA & 62,50 & & TT & 87,50 & & $\mathrm{~T}$ \\
\hline 15. & TA & 100,00 & & $\mathrm{~T}$ & 100,00 & & $\mathrm{~T}$ \\
\hline 16. & UYP & 68,75 & & $\mathrm{~T}$ & 87,50 & & $\mathrm{~T}$ \\
\hline 17. & $\mathrm{VC}$ & 68,75 & & $\mathrm{~T}$ & 75,00 & & $\mathrm{~T}$ \\
\hline \multirow[t]{4}{*}{18.} & ZT & 68,75 & & $\mathrm{~T}$ & 81,25 & & $\mathrm{~T}$ \\
\hline & Jumlah & 1306,00 & & & & & \\
\hline & Rata-rata & \multicolumn{2}{|c|}{72,57} & \multicolumn{3}{|c|}{87,15} & \\
\hline & gkat Ketuntasan & \multicolumn{2}{|c|}{$66,67 \%$} & \multicolumn{4}{|c|}{$88.89 \%$} \\
\hline
\end{tabular}

Ket: $\mathbf{T}=$ Tuntas TT $=$ Tidak Tuntas

Pada tabel di atas menunjukkan adanya peningkatan rata-rata kemampuan membaca siswa pada siklus I dan II. Pada siklus I skor rata-rata kemampuan membaca siswa adalah 72,57 , sedangkan pada siklus II mengalami peningkatan menjadi 87,15 (peningkatan sebesar 12,58 \%).
Mendeskripsikan

Peningkatan Kemampuan Membaca Siswa (Tingkat Ketuntasan Membaca Siswa ).

Pada Tabel 3 di atas menunjukkan adanya peningkatan jumlah siswa yang kemampuan membacanya di atas KKM yaitu pada siklus I sebanyak 12 orang $(66,67 \%)$, sedangkan pada siklus II berjumlah 16 orang $(88,89 \%)$, peningkatan sebesar $22,22 \%$. 
Berdasarkan analisis data yang disajikan diatas, menunjukkan bahwa pembelajaran membaca dengan menggunakan media kartu kata bergambar dapat meningkatkan kemampuan membaca permulaan pada siswa kelas I SDN 7 Pendawan Sambas.

\section{KESIMPULAN DAN SARAN Kesimpulan}

Penelitian tindakan kelas tentang penggunaan media kartu kata dapat meningkatkan kemampuan membaca siswa telah dilaksanakan dalam dua siklus, menghasilkan kesimpulan sebagai berikut: (1) Berdasarkan hasil observasi kemampuan guru menyusun RPP dengan menerapkan penggunaaan media kartu kata bergambar pada siklus I dan siklus II mengalami peningkatan. Hal ini dapat ditunjukkan pada siklus I kemampuan guru menyusun RPP mencapai skor rata-rata 3,72 , sedangkan pada siklus II meningkat menjadi 4,00; (2) Kemampuan guru melaksanakan pembelajaran dengan menggunakan media kartu kata bergambar pada siklus I dan siklus II juga mengalami peningkatan. Hal ini ditunjukkan pada siklus pertama kemampuan guru melaksanakan pembelajaran mencapai skor rata-rata 3,77 , sedangkan pada siklus II meningkat menjadi 4,00; (3) Berdasarkan analisis hasil penelitian dapat kita lihat ratarata hasil siklus I dan siklus II menunjukkan adanya peningkatan kemampuan membaca siswa. Hal ini ditunjukkan dengan skor ratarata kemampuan membaca pada siklus I 72,57 dan pada siklus II meningkat menjadi 87,15; (4) Jumlah siswa yang kemampuan membacanya di atas KKM juga mengalami peningkatan yakni siklus I berjumlah $66,67 \%$ meningkat menjadi $88,89 \%$. Hal ini berarti terjadi korelasi positif antara penggunaan media kartu kata bergambar terhadap kemampuan membaca siswa.

\section{Saran}

Telah terbuktinya penggunaan media kartu kata bergambar dapat meningkatkan kemampuan membaca siswa, maka kami sarankan hal-hal sebagai berikut: (1) Dalam kegiatan belajar membaca permulaan, diharapkan menjadikan media kartu kata bergambar sebagai suatu alternatif untuk meningkatkan kemampuan membaca permulaan; dan (2) Karena kegiatan ini sangat bermanfaat,khususnya bagi guru dan siswa, maka diharapkan kegiatan ini dapat dilakukan secara berkesinambungan dalam pelajaran untuk meningkatkan kemampuan membaca permulaan.

\section{DAFTAR RUJUKAN}

Akhadiah Sabarti, dkk. 1993. Bahasa Indonesia III. Jakarta: Proyek Pembinaan Tenaga Kependidikan Departemen Pendidikan dan Kebudayaan.

Arief S Sadiman, dkk. 1986. Media Pendidikan, pengertian, Pengembangan dan Pemanfaatannya. Jakarta: PT. Raja Grafindo Persada.

Bistari,2015. Mewujudkan Penelitian Tindakan Kelas. Pontianak: PT. Ekadaya Multi Inovasi.

Depdiknas, 2007. Program Pembelajaran Sekolah Dasar / Madrasah Ibtidaiyah Kurikulum semester 1 dan 2. Jakarta: BP. Karya Mandiri.

Harajasuna,A.S. \& Damaianti,V.S, 2003. Membaca dalam Teori dan Praktik. Bandung Mutiara.

IGAK Wardhani, dkk. 2007. Penelitian Tindakan Kelas Jakarta: Universitas Terbuka.

Jaruki, Muhammad,2008. Bahasa Indonesia Bahasa Kita Bahasa Indonesia. Jakarta: Pusat Perbukuan Diknas.

Kunandari, 2008. Langkah Mudah Penelitian Tindakan Kelas. Jakarta: PT. Rajagrafindo Persada.

Mulyasa, E. 2009. Praktik Penelitian Tindakan Kelas. Bandung: PT. Remaja Rosdakarya.

Nuriadi, 2008. Tehnik Jitu Menjadi Pembaca Terampil. Yogyakarta: Pustaka Pelajar.

Samsu Somadayo, 2011. Strategi dan Teknik Pembelajaran. Yogyakarta: Graha Ilmu 
Syafi'ie Imam,1994. Pengajaran Membaca Terpadu, Bahan Kursus Pendalaman Materi Guru Inti PKG Bahasa dan Sastra Indonesia. Malang: IKP
Tarigan Henry Guntur, 2008. Membaca Sebagai Suatu Keterampilan Berbahasa. Bandung: Angkasa. 